\title{
INCREASING OF ECOLOGICAL EFFICIENCY OF WORN EQUIPMENT BY PARTIAL UPDATES. ANALYTICAL AND CONTROL ASPECT
}

\author{
S. Voinova \\ Odessa National Academy of Food Technologies, Odessa, Ukraine \\ ORCID: 0000-0003-0203-0599 \\ E-mail: voinova_s@yahoo.com \\ Copyright $(2017$ by author and the journal "Automation technological and business - processes". \\ This work is licensed under the Creative Commons Attribution International License (CC BY). \\ http://creativecommons.org/licenses/by/4.0/
}

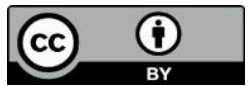

ONAFT

Open Access

Abstract: The current state of worn industrial equipment and the resulting low performance indicators of its functioning, in particular, low environmental friendliness, are considered. It is shown that the normalization of the complex situation that has developed in production is an acute problem, the solution of which should begin with the implementation of a program for the partial renewal of worn equipment. It is pointed out that there is a high potential for improving the technological, including ecological, efficiency of functioning of the upgraded equipment. It is pointed out that the partial renewal is highly efficient, because of the small specific investments in it. The significant influence of the quality of control of the setting and implementation of the renewal program on its effectiveness was noted. It is shown that the process of renewal of worn-out equipment, ultimately, has an environmental focus, increases the environmental friendliness of the updated technical facility.

Keywords: Environmental friendliness, ecological efficiency, worn-out equipment, partial renewal, technological efficiency of functioning, ecological compatibility, environmental environment, technical object, management.

\section{Introduction}

The stagnation period of development, which continues in world production, negatively affected the state of production of all countries. The analysis of the current situation shows that the operating equipment in the production facilities of Ukraine is largely worn out, the calculated service life has been fulfilled, therefore, the level of technological efficiency (TE) (E) of the operation of technical objects of such worn equipment is substantially below the level of fuel cells, domestic or foreign, operating within the estimated resource. The lowered level of fuel cells concerns all its components: ecological efficiency ( $\left.\mathrm{E}_{\mathrm{l}}\right)$, economic efficiency $\left(E_{n}\right)$ and general technical efficiency $\left(E_{o}\right)[1]$.

The current worn-out technical objects (TO), in comparison with the similarly untimely TO, consumes significantly more resources for the production of a unit of production: energy, raw materials, operating costs. This set of negative circumstances led to an environment in which production, society, and the state suffer major economic and social damage. In addition, a worn-out TO has a much greater adverse impact on the environment, which causes major environmental damage. This negative specific effect is greater, the more the TO is worn out and the higher its unit productivity (unit capacity).

Statement of problem

On the scale of the current production in Ukraine, the total negative effect created by the used worn equipment of all industries is prohibitively large and intolerable. An important problem, important in its importance and acute in its nature, was the correction of the situation created, the normalization of the state of equipment of all branches of world production.

The solution of the problem consists in raising the TE level of functioning of objects to a modern, appropriately high level. Attention is drawn to its importance, complexity and scale of the state level, as well as the urgency of solving its tasks.

The equipment operating in the domestic industry needs to be completely renewed (replaced by new equipment) or partially renewed (modernization, reconstruction or technical re-equipment).

Solving the complex problems requires a very large investment of resources of all kinds.

In the complicated economic situation prevailing in the domestic industry, the approach to solving the problems of the problem under consideration should naturally be flexible, comprehensive, systemic, taking into account the conditions, opportunities and available resources that really exist in the current production system.

A radical solution would be a complete renovation of worn out equipment, by replacing it with similar new equipment. 
However, a complete update requires the allocation of resources in volume, inaccessible to large in the current conditions and in the short term [2].

Therefore, it is actually feasible to solve the problems of the problem in the present conditions and in the period of the visible perspective, on the basis of a wide application of a partial renewal of the worn-out operating equipment [3]. At the same time, the goal should be to increase the level of all components of TE, ecological, economic and general technical.

Solutions of problem

The solution of the problem is to increase the level of TE functioning of worn-out equipment.

A radical solution would be a complete renovation of worn out equipment, by replacing it with similar new equipment. However, a complete update requires the allocation of resources in volume, inaccessible to large in the current conditions and in the short term [2].

Therefore, it is really affordable in the current conditions to implement a partial renewal of the worn-out operating equipment [3].

A partial update has a twofold meaning:

- it is necessary to update the part of the worn out equipment that needs it to the greatest extent, that is, the part capable of ensuring the greatest positive specific effect of partial renewal,

- in the object subjected to a partial update, it is necessary to update those parts of it (a technology element, a construction element or an operating mode element) that contribute to obtaining the greatest positive specific effect of partial renewal.

Partial updating of the worn out TO is a complex controlling influence on its properties: on the level of its $\mathrm{E}_{1}$, on the level of its $E_{n}$ and on its level $E_{o}$, with the purpose of their increase. Thus, a partial update is a process of managing the basic, strategic (technology-related) and tactical (design-related) properties and the level of the TE of the operating TO. During the operation of the updated TO, the automatic control system (ACS) performs operational control of the mode of its operation [4].

During the partial updating of the TO, changes can also be made to the system of TO activities. It should be specially noted that any measure of the partial renewal program aimed at raising the level of one of these components of the TO TE also affects the level of the other two components.

In the partial renewal program, it is important to ensure the provision of a high level of environmental efficiency (El) of the updated TO [5].

The partial renewal program may have a different scale, that is, it can be calculated for the equipment of a production site, shop, enterprise, or industry. It can have a different duration of implementation of a set of planned activities. The creation and implementation of a partial renewal program, regardless of its scale, requires the involvement of high-level experts in technical culture and business qualification. The set of program activities should be based on an integrated-system approach.

Scientific and organizational-technical solutions used in the program of partial renewal of worn-out equipment of a specific production facility should be innovatively saturated and rely in their structure, the volume of parts and the sequence of their implementation on a system-system approach.

Structural objects in various industries of domestic production have real opportunities for partial renovation of worn-out equipment. The amount of the upgrade program in each individual case is determined by the available resource.

It should be noted that the use of a selective approach in the implementation of a partial update of a group of worn-out technical objects speeds up the receipt of both the current and the many-sided final total positive result due to the update.

In addition, selective updating accelerates the accumulation of organizational and technological experience among organizers and performers of works, and this accelerates the receipt and increases the volume of the total positive effect of their implementation.

The large-scale task of partial updating of old technical objects attracts attention. It is also complex (cumbersome) in scientific and organizational-technical terms. At the same time, the degree of urgency of the solution of this problem increases with acceleration.

In the presence of resource support, it is advisable to combine the partial update with the full updating of a separate part of TO.

It is important to note that the program for the partial updating of the TO elements should also contain an organizational and technical section devoted to the tasks of updating the operating modes of these elements (carrying a multifaceted production load) on the basis of the use of new, modern, innovative saturated approaches and scientific and technical solutions.

The program should also contain a section on the tasks of updating the maintenance (operational and repair) equipment of production facilities.

In the problem of partial updating of TO, proper attention must be paid to the task of increasing the level of ecological efficiency of the functioning of all its parts. It is known that the most aggressive source of harmful impact on the environment is the most important of the leading industries - energy. Evidence of this is the energy saving program adopted in Europe, which has a purely environmental nature. Partial renewal of energy TO, ultimately, pursues the goal of energy saving, and the process of energy conservation has, as you know, an ecological entity. The environmental aspect should be a red thread through all the tasks of renewing energy equipment [6]. It is of fundamental importance to ensure a state of affairs in which, in the process of updating worn-out equipment, the use of innovatively rich scientific and organizational-technical solutions would not be an opportunity or an excuse, but a rigid responsibility of developers and executors of the renewal program.

A special position among the tasks of the partial updating of the TO is the task of improving the quality of management of the process of its functioning, in its broad sense. Here, under the management task, it is necessary to understand not only the 
traditional control of the operation of the TO with the help of local ACS. It should be borne in mind the possibility of influencing other factors affecting the level of equipment TE: to make a choice and use the best technological solution, constructive solution, mode solution, algorithm of automatic control system. Such a comprehensive approach to setting and solving the task of TO control is able to provide the highest result - the highest level (from the number available in specific conditions) of the TE of the renewed system.

Solving the tasks of updating the TO will be a major achievement in the direction of raising the level of TE of functioning of domestic production, especially its environmental friendliness.

Among the main factors influencing the level of social and technological efficiency of the renewal of industrial equipment, the personnel potential of developers and executors of the complex of works on the tasks of this program plays a decisive role. An important condition for raising the level of technological efficiency of production is the level of professional qualification and technical culture of workers in all branches of production. In terms of this problem, the role of systemic training of personnel in the education system and the role of the technical training system operating at TO is important.

There is reason to believe that, under current conditions, the pace of implementation of a program for the renewal of wornout equipment will depend significantly on the economic conditions for the development of industries.

As a result of the analysis of the current state of the existing TO in Ukraine and the possibility of their development in the visible perspective, there is reason to believe that a partial update is a productive tool in solving the problem of raising the level of TE of these TO.

In solving problems of this problem, the psychological aspect is important, that is, the level of awareness of the company's management about a really affordable positive complex (including economic) effect that can provide partial renewal.

In general, partial renewal of existing worn-out equipment is a high-quality, productive tool for controlling the level of fuel cell functioning of this equipment.

Conclusions

1. A significant part of the production equipment is extremely worn, Therefore it functions with a low TE level.

2. To improve the situation, it is necessary to improve the quality of the equipment state management and the mode of its operation.

3. The state of worn-out equipment can be managed by updating it, and control of its operation mode is possible, by improving the control algorithm of ACS with the corresponding production facilities.

4. The improvement of the condition of worn-out equipment is now really possible, by means of its partial renewal of production.

5. Partial renewal is a flexible, productive method of increasing the level of all components of the TO functioning TE.

6. Of particular importance is the possibility of increasing the level of the environmental component of the TE process of the functioning of a worn out TO.

7.When drawing up a program for partial renewal of worn out TO, the degree of wear of each of the TO elements, the appropriate scope and sequence of implementation of the stages of partial renewal, as well as the specific resource intensity of the execution of parts of the program should be taken into account.

8. The program of partial renewal of worn-out TO should be complex-systemic.

9. The last stage of partial updating of the worn out TO service should be a partial update of the ACS by this object.

10. Scientific and organizational-technical solutions used for partial renewal of worn out TO, must be innovative saturated.

11. An important property of the process of partial renewal of worn out TO is its profitability.

\section{Referenses}

[1] Itogi rabotyi promyishlenosti Ukrainyi v i polugodii 2017 goda, Monitoringovyie produktyi, Analiticheskiy tsentr «Novaya sotsialnaya i ekonomicheskaya politika», 24.07.2017. URL: http://newsep.com.ua/new/1016.

[2] S.A. Voinova O probleme upravleniya effektivnostyu funktsionirovaniya iznoshennogo oborudovaniya, Energetika ta elektrifikatsiya, № 8, pp. 36 - 39, 2016.

[3] S.A. Voinova Obnovlenie kak instrument razvitiya proizvodstva, Izvestiya vuzov i energeticheskih ob'edineniy SNG, № 2, pp. $69-74,2013$.

[4] S.A Voinova Chastkove onovlennya - Innovatsiyniy instrument upravlinnya efektivnistyu funktsionuvannya ustatkuvannya, scho vidrobilo resurs, Avtomatizatsiya tehnologichnih i biznes-protsesiv, Volume 8, Issue 1, pp. 71 $76,2016$.

[5] S.A. Voinova Aktualnyie zadachi upravleniya ekologicheskoy effektivnosti tehnicheskih ob'ektov, Conference "Strategiya kachestva v promyishlennosti i obrazovaniya” Dnipropetrovsk - Varna: "Fortuna", T.1, pp. 102 - 104, June $1-8,2007$

[6] A.P.Voinov, Zh.V. Dimitrova, S.A. Voinova Aktualnost obnovleniya oborudovaniya v sistemah tsentralizovannogo teploobespecheniya vozrastaet s uskoreniem, Conf. "Suchasne misto — problemi ta Yih virishennya", Odesa: ODABA, pp. 91 - 92, September 21-23, 2017

\section{Література}

[1] Итоги работы промышлености Украины в I полугодии 2017 года (Электронный ресурс) / Мониторинговые продукты / Аналитический центр «Новая социальная и экономическая политика», 24.07.2017. URL: 
http://newsep.com.ua/new/1016.

[2]Воинова С.А. О проблеме управления эффективностью функционирования изношенного оборудования / Енергетика та електрифікація, 2016, №. 8.- С. 36 - 39.

[3]Воинова С. А. Обновление как инструмент развития производства/ Известия вузов и энергетических объединений СНГ, № 2, 2013.- С. 69 - 74.

[4]Воинова С. А. Часткове оновлення - інноваційний інструмент управління ефективністю функціонування устаткування, що відробило ресурс / Автоматизація технологічних і бізнес-процесів, 2016, Volume 8, Issue 1.- C. $71-76$.

[5]Воинова С. А. Актуальные задачи управления экологической эффективности технических объектов/ Матер. Междун. конф. “Стратегия качества в промышленности и образования” (1-8 июня 2007г., Варна, Болгария). Дніпропетровськ - Варна: “Фортуна”. - ТУ Варна - 2007г., - Т.1. - С.102 - 104.

[6]Воинов А.П., Димитрова Ж.В., Воинова С.А. Актуальность обновления оборудования в системах централизованного теплообеспечения возрастает с ускорением / Зб. тез допов. Міжнар. наук.-практ. конф. “Сучасне місто - проблеми та їх вирішення”, 21 - 23 вересня 2017р., Одеса.- Одеса: ОДАБА.- С. 91 - 92.

\title{
OVERVIEW OF POPULAR APPROACHES IN CREATING CLIENT-SERVER APPLICATIONS BASED ON SCIENTOMETRICS ONAFTS' PLATFORM
}

\author{
D. Salskyi ${ }^{1}$, A. Kozhukhar ${ }^{2}$, O. Olshevska ${ }^{3}$, N. Povarova ${ }^{4}$ \\ ${ }^{1,2,3,4}$ Odessa National Academy of Food Technologies, Odessa, Ukraine \\ ORCID: ${ }^{3} 0000-0002-4512-3915,{ }^{4} 0000-0003-3630-8384$ \\ Scopus ID: ${ }^{3} 57192687506,{ }^{4} 56578764800$ \\ E-mail: ${ }^{1}$ salsky.d@gmail.com, ${ }^{2}$ alex.kozhuchar@gmail.com, ${ }^{3}$ olshevska.olga@gmail.com, ${ }^{4}$ povarova.natasha@gmail. \\ Copyright (C) 2017 by author and the journal "Automation technological and business - processes". \\ This work is licensed under the Creative Commons Attribution International License (CC BY). \\ http://creativecommons.org/licenses/by/4.0/
}

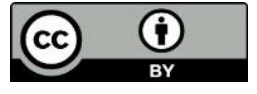

ONAFT

Open Access

Abstract: Most of the currently developed systems are based on the client-server architecture. This architecture is used everywhere, from mobile-native development to Web applications.

However implementing an application based on this architectural solution requires quite a lot of effort from the software developer, and therefore, in order to simplify and speed up the development, certain standard solutions and approaches appeared. This article will discuss the most popular technologies used in the development of Web applications in the context of enterprise development.

Also in this article will be mentioned the project, built on the architecture of "client-server" - ScienceToMetrics.

The main theme of this project is the study of science-metric indicators for the structural divisions of the faculty of the Odessa National Academy of Food Technologies. In fact, it is a portal for viewing and editing information on employees, in the future this portal may be extended to subprojects.

In this project, the main idea of this architecture was embodied: decomposition of the application into atomic parts in order to distribute it to several hardware units of capacity to improve performance. The client is an independent application, which at the same time receives information from an external API-interface through REST-requests. In turn, the backend provides this API with certain security restrictions on the content provided. The backend for this architecture provides a layer for the content of the data users, whether it's a database (NoSQL, SQL) or an integration API with external aggregation systems. To ensure the necessary level of security, JWT (Javascript Web Token) authorization is used, which allows you not to create an explicit session between the client and the backend, but allows you to communicate through a token that stores all the necessary meta-information for this user. 